P-ISSN 2580 - 7781

E-ISSN 2615 - 3238

\title{
UPAYA MENINGKATKAN KESEHATAN ANAK PADA MASA PANDEMI COVID-19 DI DESA AEK HARUAYA
}

\section{EFFORTS TO IMPROVE CHILD HEALTH DURING THE COVID-19 PANDEMIC IN AEK HARUAYA VILLAGE}

\author{
Hasan Syukur Siregar ${ }^{1)}$, Ika Herawati Siregar ${ }^{2)}$, Riski Efrina Siregar ${ }^{3)}$, Nurhidayah \\ Simbolon $^{4}$, Amiruddin Siahaan ${ }^{5}$ \\ 1,2,3,4,5,6 Universitas Islam Negeri Sumatera Utara Medan \\ ${ }^{1}$ Email: sukurhasan867@gmail.com
}

\begin{abstract}
ABSTRAK
Penelitian ini bertujuan untuk menganalisa upaya meningkatkan kesehatan anak pada masa pandemi Covid-19 di Desa Aek Haruaya, khususnya peran ibu. Sebab, peran ibu adalah hal yang paling utama agar kesehatan pada anak tidak menurun. Hal ini dimaksudkan sebagai upaya meningkatkan kesehatan anak di Desa Aek Haruaya, terutama pada masa Covid-19. Penelitian ini menggunakan pendekatan kualitatif dengan metode deskriptif analitis. Pengumpulan data dilakukan menggunakan teknik observasi, wawancara dan kajian dokumen. Selanjutnya, dianalisis menggunakan cara data reduction, display data, dan verification. Hasil penelitian ini menunjukkan bahwa perlu dilakukan beberapa pencegahan dan penyuluhan kepada ibu-ibu di Desa Aek Haruaya. Hal pencegahan yang dapat dilakukan yaitu pertama, memberikan imunisasi kepada anak-anak usia batita dan di bawahnya. Bukan hanya itu saja, mahasiswa/i KKN juga melakukan beberapa penyuluhan seperti, cara mencuci tangan yang benar dan bertujuan untuk meningkatkan pengetahuan ibu-ibu tentang kaidah mencuci tangan, dengan harapan agar anak-anak tidak terjangkit diare dan mencegah masuknya virus ke dalam tubuh anak. Kedua membuat apotek hidup di sekitar pekarangan rumah yang kosong. Hasil dari kegiatan tersebut diharapkan dapat mengoptimalkan peran ibu-ibu di Desa Aek Haruaya agar terwujud pola hidup sehat pada anak-anak.
\end{abstract}

Kata kunci: Apotek hidup, Imunisasi, Mencuci tangan, Peran ibu

\begin{abstract}
This study aims to analyze efforts to improve children's health during the COVID-19 pandemic in Aek Haruaya Village, especially the role of mothers. Therefore, the role of the mother is the most important thing so that the health of the child does not decline. This is intended as an effort to improve the health of children in Aek Haruaya Village, especially during the Covid-19 period. This study uses a qualitative approach with analytical descriptive method. Data was collected using observation, interview and document review techniques. Furthermore, it is analyzed using data reduction, data display, and verification methods. The results of this study indicate that it is necessary to do some prevention and counseling to mothers in Aek Haruaya Village. Prevention things that can be done are first, giving immunizations to children aged under five and under. Not only that, KKN students also carried out several counseling such as how to wash hands properly and aimed at increasing mothers' knowledge about hand washing rules, with the hope that children would not contract diarrhea and prevent the entry of viruses into the child's body. . The second makes the pharmacy live around the empty yard of the house. The results of these activities are expected to optimize the role of mothers in Aek Haruaya Village in order to realize a healthy lifestyle for children.

Keywords: Life pharmacy, Immunization, Hand washing, Mother's role.
\end{abstract}


P-ISSN 2580 - 7781

E-ISSN 2615 - 3238

\section{PENDAHULUAN}

Desa Aek Haruaya merupakan desa yang terletak di Kecamatan Portibi Kabupaten Padang Lawas Utara dengan luas wilayah 4,06 $\mathrm{km}^{2}$. Desa Aek Haruaya memiliki 1.530 jiwa yang rata-rata warganya adalah warga bermarga (Batak Angkola). World Health Organization (WHO) melaporkan bahwa terjadi penurunan angka kematian balita (AKB) pada tahun 1990-2013. Pada tahun 1990 kematian balita sebesar 12,6 juta anak, sedangkan pada tahun 2013 kematian balita sebesar 6,3 juta anak. Menurut Kemenkes RI (2014) angka kematian balita pada tahun 2015 masih jauh dari target AKB yaitu sebesar 23 per 1000 kelahiran hidup. AKB secara global di dunia masih tinggi yaitu sebesar 46 per 1000 kelahiran hidup.

Masyarakat Desa Aek Haruaya sejatinya sudah melakukan kegiatan imunisasi dengan baik setiap bulannya yang diadakan di Poskesdes dan balai Desa Aek Haruaya. Imunisasi adalah suatu upaya untuk meningkatkan kekebalan seseorang secara aktif terhadap suatu penyakit, sehingga bila suatu saat terpapar dengan penyakit tersebut tidak akan sakit atau hanya mengalami sakit ringan. Bidan desa dibantu oleh mahasiswa UINSU dalam melaksanakan kegiatan program imunisasi di Poskesdes Desa Aek Haruaya Kec. Portibi sudah baik. Hal ini ditandai dengan pelaksanaan program dan laporan bulanan dilakukan dengan tepat waktu.

Pengetahuan ibu tentang kebersihan anak maupun kebersihan lingkungan memegang peranan penting pada tumbuh kembang anak baik fisik maupun psikisnya. Kebersihan anak yang kurang, akan memudahkan terjadinya penyakit cacingan dan diare pada anak (Notoatmodjo, 2014). Pendidikan dan pengetahuan yang cukup harus dimiliki oleh ibu, maka ibu dapat mengetahui bagaimana cara menciptakan lingkungan yang baik dan layak untuk tumbuh kembang anak, sehingga meningkatkan rasa aman bagi anak.

Budidaya tanaman apotek hidup dipandang tepat pada kondisi saat ini, karena dapat digunakan sebagai obat-obatan tradisional guna mengobati atau mengatasi berbagai penyakit apalagi saat ini dalam masa pandemi Covid-19, di mana diperlukan imunitas yang cukup dan bagus. Sehingga dapat memicu 
P-ISSN 2580 - 7781

E-ISSN 2615 - 3238

masyarakat akan kesadaran dan ketertarikan menanam tanaman apotek hidup pada halaman rumah, meningkatkan pengetahuan masyarakat akan pemanfaatan lahan pekarangan rumah untuk penanaman tumbuhan apotek hidup, serta memberikan pengetahuan masyarakat tentang tanaman yang dapat digunakan untuk obat sebagai apotek hidup.

\section{METODE PENELITIAN}

Dalam melakukan kegiatan imunisasi dilakukan secara luring (langsung) di balai desa dan Poskesdes Desa Aeh Haruaya, yang dilaksanakan oleh bidan desa, kader-kader Poskesdes serta mahasiswa/i KKN. Tidak berbeda juga dengan kegiatan penyuluhuan mencuci tangan yag dilakukan di balai desa kepada masyarakat dengan memenuhi protokol kesehatan, dan kegiatan apotek hidup juga dilakukan di beberapa lahan yang kosong yang berada dekat dengan permukiman warga.

\section{HASIL PENELITIAN DAN PEMBAHASAN}

\section{Imunisasi}

Berdasarkan dari kegiatan yang sudah dilakukan bahwa peran bidan dan kader poskesdes di Desa Aek Haruaya sudah berjalan optimal, karena dilakukan secara rutin per bulannya, namun peran dan antusias dari ibu-ibu Desa Aek Haruaya masih kurang, karena di lapangan ditemukan hanya beberapa ibu saja yang datang saat imunisasi, dan ketika dilihat dari buku panduan terkadang ada sebagian ibu yang imunisasi baru 2 kali dalam 6 bulan terakhir.

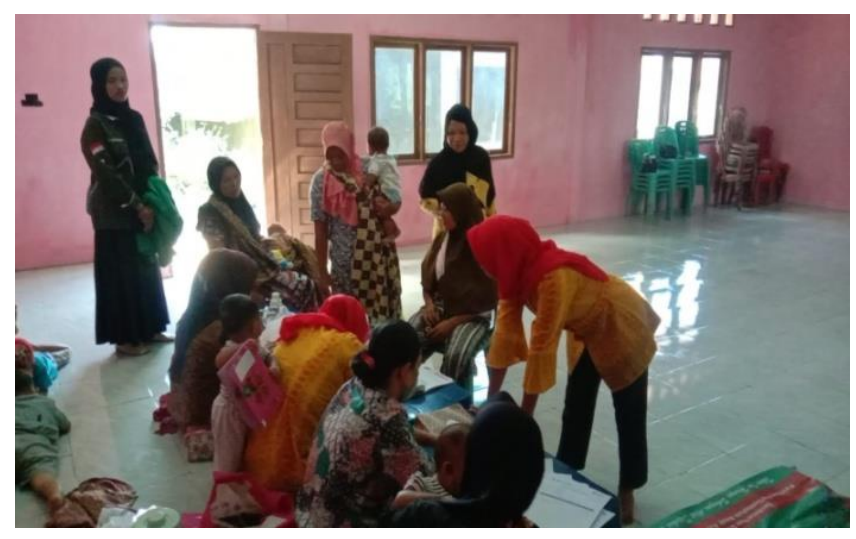

Gambar 1. Pendataan Imunisasi anak dan ibu di Desa Aek Haruaya 
P-ISSN $2580-7781$

E-ISSN 2615 - 3238

\section{Mencuci Tangan dengan Baik}

Berdasarkan hasil penelitian bahwa ibu-ibu Desa Aek Haruaya masih banyak yang mencuci tangan dengan menggunakan air saja dan hanya disiram begitu saja, dan pengetahuan mereka masih minim akan cuci tangan yang baik dan benar, padahal di sekitar balai desa dan poskesdes sudah ada beberapa spanduk cara mencuci tangan.

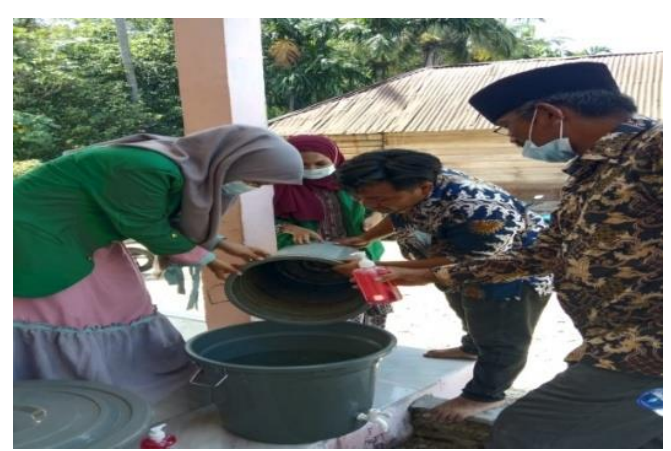

Gambar 2. Kegiatan Pembuatan Handsoap.

Mencuci tangan pakai sabun merupakan intervensi kesehatan yang paling murah dan efektif dibandingkan dengan intervensi kesehatan dengan cara lainnya dalam mengurangi risiko penularan berbagai penyakit salah satunya Covid-19 dan diare terutama pada anak-anak. Kebiasaan tidak melakukan cuci tangan dengan cara yang tidak benar menyebabkan kuman masuk melalui tangan yang terkontaminasi oleh kotoran atau tinja dan virus jahat lainnya. Pada kegiatan ini mahasiswa/i KKN juga melakukan kegiatan pembuatan handsoap untuk digunakan dalam mencuci tangan. Dan di tempatkan pada lokasi umum dan yang sering dikunjungi warga Desa Aek Haruaya.

\section{Apotek Hidup}

Berdasarkan hasil penelitian warga Desa Aek Haruaya ada yang sudah mempunyai apotek hidup tersendiri di lahan sekitar rumahnya, namun mereka menggunakannya sebagai bahan dapur saja, mereka tidak mengetahui bahwa tanaman tersebut dapat dijadikan obat tradisional untuk menjaga sistem imun dalam tubuh, terutama di masa pandemi Covid-19 ini. Sistem imun tubuh harus tetap dijaga agar tidak mudah diserang oleh virus. 
P-ISSN 2580 - 7781

E-ISSN 2615 - 3238

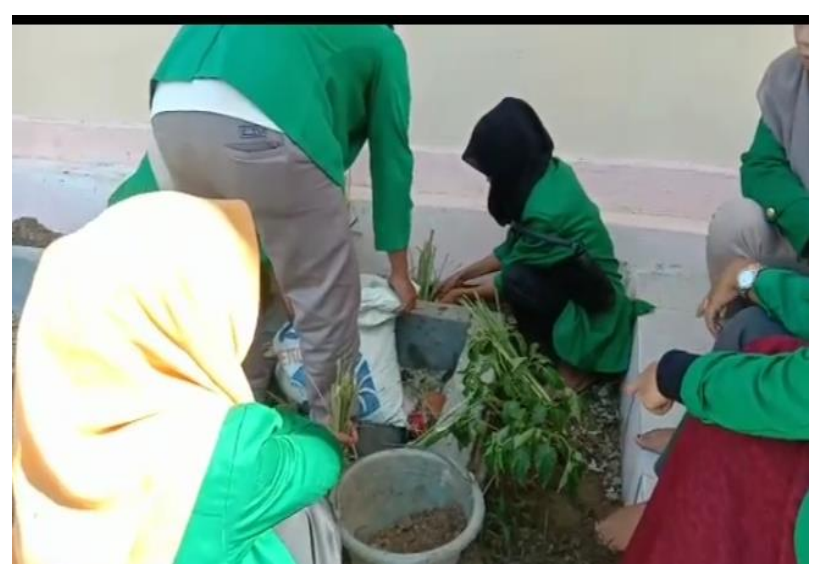

Gambar 3. Kegiatan Penanaman Apotek Hidup.

Macam-macam tanaman yang dapat dijadikan sebagai apotek hidup ialah: jahe, kunyit, temulawak, kencur, serai dan lain-lain (Yoganingrum, 1999). Tanaman tersebut selain dapat digunakan untuk bumbu dapur dapat juga dibuat sebagai obat tradisional untuk asma, anti inflamasi, menambah nafsu makan, menyegarkan tubuh, mengobati diare, masuk angin dan lain sebagainya (Santoso, 1994).

\section{KESIMPULAN}

Berdasarkan dari penelitian yang dilakukan bahwa perilaku ibu-ibu di Desa Aek Haruaya dalam meningkatkan kesehatan pada anak sudah lumayan bagus, hanya ada beberapa poin saja yang warga Desa Aek Haruaya belum mengetahuinya dan sudah diberikan masukan ketika kegiatan penyuluhan baik dalam kegiatan imunisasi, mencuci tangan, dan penanaman apotek hidup.

\section{DAFTAR PUSTAKA}

Kemenkes RI. 2014. Data dan Informasi Tahun 2013 (Profil Kesehatan Indonesia). Jakarta: Kemenkes RI.

Notoatmodjo, S. 2014. Promosi Kesehatan dan Perilaku Kesehatan. Jakarta: Rineka Cipta.

Santoso, HB. 1994. Jahe Gajah. Yogyakarta: Kanisius.

Yoganingrum. A. 1999. Paket Informasi Teknologi Budidaya dan Pasca Panen. Jakarta: Pusat Dokumentasi dan Informasi Ilmiah-LIPI. 